\title{
Will Mass Spectrometry Replace Current Techniques for Both Routine Monitoring and MRD Detection in Multiple Myeloma?
}

\author{
Katie L. Thoren
}

check for

updates

Citation: Thoren, K.L. Will Mass Spectrometry Replace Current Techniques for Both Routine Monitoring and MRD Detection in Multiple Myeloma? Hemato 2021, 2 764-768. https://doi.org/10.3390/ hemato2040052

Academic Editor: Fredrik Schjesvold

Received: 12 November 2021

Accepted: 4 December 2021

Published: 9 December 2021

Publisher's Note: MDPI stays neutral with regard to jurisdictional claims in published maps and institutional affiliations.

Copyright: (C) 2021 by the author. Licensee MDPI, Basel, Switzerland. This article is an open access article distributed under the terms and conditions of the Creative Commons Attribution (CC BY) license (https:/ / creativecommons.org/licenses/by/ $4.0 /)$.
Clinical Chemistry Service, Department of Laboratory Medicine, Memorial Sloan Kettering Cancer Center, New York, NY 10065, USA; thorenk@mskcc.org

\begin{abstract}
In recent years, mass spectrometry has been increasingly used for the detection of monoclonal proteins in serum. Mass spectrometry is more analytically sensitive than serum protein electrophoresis and immunofixation, can help distinguish therapeutic monoclonal antibodies from M-proteins, and can detect the presence of post-translational modifications. Mass spectrometry also shows promise as a less-invasive, peripheral-blood-based test for detecting minimal residual disease in multiple myeloma. Studies comparing the clinical utility of mass spectrometry to current blood- and bone-marrow-based techniques have been conducted. Although still primarily limited to research settings, clinical laboratories are starting to adopt this technique for patient care. This review will discuss the current status of mass spectrometry testing for multiple myeloma, the benefits and challenges of this technique, and how it may be incorporated into clinical practice in the future.
\end{abstract}

Keywords: mass spectrometry; monoclonal immunoglobulin; multiple myeloma

\section{Introduction}

Treatments for multiple myeloma have greatly improved over the last decade and new diagnostic methods are being developed to detect lower levels of disease. Mass spectrometrybased methods that detect the monoclonal immunoglobulin (M-protein) have been developed and offer several analytical advantages over electrophoretic techniques [1-4]. They are more analytically sensitive and specific than serum protein electrophoresis (SPEP) and immunofixation (IF). They also provide additional information about the protein (i.e., light chain glycosylation) that is not available by SPEP and IF. Because these techniques are still relatively new, the field is trying to determine how (and if) these analytical advantages will improve patient care and where these assays fit into clinical practice. In this review, we discuss the different mass spectrometry methods, our current understanding of their clinical utility, and whether they may overtake current techniques for both routine monitoring and MRD detection in multiple myeloma.

\section{Mass Spectrometry Methods}

Several mass spectrometry methods have been developed to detect the M-protein in serum and have been reviewed previously [1-4]. Typically, methods either follow the intact light chain or clonotypic peptides as a marker of the M-protein. One common approach uses matrix-assisted laser desorption ionization time-of-flight mass spectrometry (MALDITOF MS) to follow intact light chains and offers a high-throughput testing option [5]. Other approaches include liquid chromatography high resolution mass spectrometry (LC-HRMS) to follow the intact light chain [6,7] or clonotypic peptides [8-11]. LC-HRMS systems are more expensive and complex compared to MALDI-TOF MS but offer better analytical sensitivity. The limit of detection of mass spectrometry assays ranges from about 0.05 to $0.001 \mathrm{~g} / \mathrm{dL}$ and largely depends on type of mass spectrometer used. The clinical utility of these mass spectrometry assays is being evaluated at all stages of disease: screening and diagnosis [12-14], routine monitoring [12,15], assessment of minimal residual disease (MRD) [11,16-20], and detection of relapse $[9,21,22]$. 


\section{Clinical Utility}

\subsection{Minimal Residual Disease (MRD)}

The improved analytical sensitivity is perhaps the most exciting aspect of these methods and will be most impactful for monitoring low levels of disease since few alternative blood-based methods are available. Compared to bone-marrow-based tests, a highly sensitive blood-based test would be cheaper and less painful for the patient. It would also allow for the detection of extramedullary disease and offer an easier way to serially monitor patients.

Several studies have evaluated the role of mass spectrometry in the setting of MRD. Both MALDI-TOF MS and LC-HRMS methods have been compared to bone-marrow-based MRD techniques, including IMWG-recommended next-generation flow (NGF) and nextgeneration sequencing (NGS) methods that have a sensitivity of $10^{-5}$ to $10^{-6}[11,16-20]$. In general, concordance between mass spectrometry and bone-marrow-based MRD techniques ranges from about $60 \%$ to $80 \%[11,17,19,20,23]$. Discrepant samples are often negative by bone marrow-based techniques, but positive by mass spectrometry. This trend may be partly explained by the long half-life of some immunoglobulins. However, comparisons to progression free survival (PFS) suggest that this confounding factor can be overcome and that mass spectrometry may be more sensitive than bone-marrow-based MRD tests. For instance, in one study that compared LC-HRMS to NGS analysis of bone marrow, there were 22 NGS/LC-HRMS+ cases but no NGS+/LC-HRMS- cases [19]. Five of the NGS-/LC-HRMS+ cases experienced progression. None of the patients who were negative by LC-HRMS experienced progression or death. Other studies have similar findings $[9,20]$. In addition, longer PFS is significantly associated with decreasing M-protein levels [11,18]. In other words, the rate of change of the M-protein appears to be more reflective of disease status than presence of the M-protein at single time points, and may provide a solution to the long half-life issue. Once the M-protein is cleared, mass spectrometry shows promise for detecting early relapse. In two separate studies, LC-HRMS detected an increase in the M-protein concentration months earlier than standard analysis $[9,21]$.

Although there is some evidence that mass spectrometry is more sensitive and may be a better predictor of progression than bone-marrow-based MRD tests, the longest progression free survival (PFS) is observed in patients who are negative by both mass spectrometry and bone-marrow-based MRD tests, suggesting that the techniques are complementary $[11,17,19]$. The current thinking is that mass spectrometry will probably not completely replace bone-marrow-based techniques. Bone marrow analysis provides information that is not achieved with other methods and is still important for monitoring non-secretory disease. Combination of blood-, bone-marrow- and imaging-based techniques may be important for establishing MRD negativity. But once established, mass spectrometry will likely become a valuable technique for MRD monitoring and detecting early relapse, since it is well-suited for serial sampling. This may be particularly important since persistence of MRD negativity is strongly associated with better outcome [24]. More studies with larger cohorts are needed to fully understand the clinical utility of measuring low levels of the M-protein, and the field is currently focused on this issue. Down the road, it will also be important to consider practical factors that affect the incorporation of these assays into MRD testing algorithms, like the complexity of the tests, the cost/benefit of using mass spectrometry versus other techniques, and the best timing of these assays.

\subsection{High Levels of Disease}

The clinical utility of mass spectrometry is also being evaluated at diagnosis and high levels of disease. MALDI-TOF MS is thought to be more appropriate for routine monitoring of M-proteins due to its high throughput and ease of use. Studies comparing the performance of MALDI-TOF MS to the standard panel of tests (SPEP, IF, free light chain quantitation, urine protein electrophoresis, and urine IF) have shown that the technique provides comparable clinical sensitivity and specificity for detection of various monoclonal gammopathies [12]. The International Myeloma Working Group also recently endorsed the use of MALDI-TOF MS as 
an alternative to IF, with the caveat that complete response rates would likely be different due to the improved analytical sensitivity of MALDI-TOF MS [25].

Although MALDI-TOF MS is currently being used as a replacement for IF at one major reference laboratory in the United States [26], it will likely take some time before this technique is adopted on a wider scale for routine testing. This is because changes to diagnostic testing require a large investment of time, energy, and money, and new methods must substantially improve patient care or offer major practical advantages for most clinical laboratories to justify the switch from well-established techniques. Because there is less clinical need for improved sensitivity at diagnosis and during early stages of therapy when M-protein concentrations are high, mass spectrometry does not yet offer major clinical advantages over electrophoretic techniques in this setting. The technique is more specific compared to SPEP and IF, which is important for distinguishing the M-protein from monoclonal antibody drugs $[27,28]$. However, commercially available electrophoretic methods are already available for this purpose, albeit these methods are limited to specific drugs and are reflex tests, adding to the turn-around time of results $[29,30]$. Although the ability to detect light chain glycosylation is a unique advantage of mass spectrometry, the clinical utility of this finding is still being evaluated [31-33].

Instead, practical considerations such as turn-around time, cost, ease of use, or consolidation of tests, may drive the widespread adoption of mass spectrometry for routine testing. Mayo Clinic reports that their assay, termed MASS-FIX, can process 320 samples in an 8-hour shift with one technologist, which equates to a 3-fold increase in productivity compared to immunofixation [26]. It would be interesting to compare the throughput of mass spectrometry to more automated electrophoretic techniques, such as capillary protein electrophoresis and immunosubtraction. Experience from additional laboratories and cost analyses compared to electrophoretic techniques will also be important. For now, we will likely see mass spectrometry assays limited to large academic centers or reference laboratories which have both the resources (i.e., time, money, and technical expertise) and demand for these tests for clinical research purposes. With these early adopters, we will learn more about the advantages and disadvantages of mass spectrometry for routine testing.

\section{Conclusions}

There is much excitement around the use of mass spectrometry for detecting Mproteins. More work is needed to understand how the analytical advantages of mass spectrometry improve patient outcome and how the technique fits in with current testing strategies. It is also important to understand the practical advantages for the clinical laboratory. All of this takes time, effort, and collaboration on the part of researchers, clinicians, clinical laboratorians, in vitro diagnostic companies, and others. Regardless of how and when mass spectrometry is incorporated into the clinical laboratory, this work is helping to better understand the disease and drive improvement of existing techniques and testing strategies, ultimately leading to better patient care.

Funding: This research received no external funding.

Institutional Review Board Statement: Not applicable.

Informed Consent Statement: Not applicable.

Data Availability Statement: Not applicable.

Conflicts of Interest: K.L.T. has received research support from The Binding Site and Sebia, Inc.

\section{References}

1. Chapman, J.R.; Thoren, K.L. Tracking of Low Disease Burden in Multiple Myeloma: Using Mass Spectrometry Assays in Peripheral Blood. Best Pract. Res. Clin. Haematol. 2020, 33, 101142. [CrossRef]

2. Thoren, K.L. Mass Spectrometry Methods for Detecting Monoclonal Immunoglobulins in Multiple Myeloma Minimal Residual Disease. Semin. Hematol. 2018, 55, 41-43. [CrossRef] 
3. Murray, D.L.; Dasari, S. Clinical Mass Spectrometry Approaches to Myeloma and Amyloidosis. Clin. Lab. Med. 2021, 41, 203-219. [CrossRef]

4. Zajec, M.; Langerhorst, P.; VanDuijn, M.M.; Gloerich, J.; Russcher, H.; van Gool, A.J.; Luider, T.M.; Joosten, I.; de Rijke, Y.B.; Jacobs, J.F.M. Mass Spectrometry for Identification, Monitoring, and Minimal Residual Disease Detection of M-Proteins. Clin. Chem. 2020, 66, 421-433. [CrossRef] [PubMed]

5. Mills, J.R.; Kohlhagen, M.C.; Dasari, S.; Vanderboom, P.M.; Kyle, R.A.; Katzmann, J.A.; Willrich, M.A.V.; Barnidge, D.R.; Dispenzieri, A.; Murray, D.L. Comprehensive Assessment of M-Proteins Using Nanobody Enrichment Coupled to MALDI-TOF Mass Spectrometry. Clin. Chem. 2016, 62, 1334-1344. [CrossRef] [PubMed]

6. Barnidge, D.R.; Dasari, S.; Botz, C.M.; Murray, D.H.; Snyder, M.R.; Katzmann, J.A.; Dispenzieri, A.; Murray, D.L. Using Mass Spectrometry to Monitor Monoclonal Immunoglobulins in Patients with a Monoclonal Gammopathy. J. Proteome Res. 2014, 13, 1419-1427. [CrossRef] [PubMed]

7. Santockyte, R.; Puig, O.; Zheng, N.; Ouyang, Z.; Titsch, C.; Zhang, Y.J.; Pillutla, R.; Zeng, J. High-Throughput Therapeutic Antibody Interference-Free High-Resolution Mass Spectrometry Assay for Monitoring M-Proteins in Multiple Myeloma. Anal. Chem. 2021, 93, 834-842. [CrossRef]

8. Martins, C.O.; Huet, S.; Yi, S.S.; Ritorto, M.S.; Landgren, O.; Dogan, A.; Chapman, J.R. Mass Spectrometry-Based Method Targeting Ig Variable Regions for Assessment of Minimal Residual Disease in Multiple Myeloma. J. Mol. Diagn 2020, 22, 901-911. [CrossRef]

9. Liyasova, M.; McDonald, Z.; Taylor, P.; Gorospe, K.; Xu, X.; Yao, C.; Liu, Q.; Yang, L.; Atenafu, E.G.; Piza, G.; et al. A Personalized Mass Spectrometry-Based Assay to Monitor M-Protein in Patients with Multiple Myeloma (EasyM). Clin. Cancer Res. 2021, 27, 5028-5037. [CrossRef]

10. Zajec, M.; Jacobs, J.F.M.; Groenen, P.J.T.A.; de Kat Angelino, C.M.; Stingl, C.; Luider, T.M.; De Rijke, Y.B.; VanDuijn, M.M. Development of a Targeted Mass-Spectrometry Serum Assay to Quantify M-Protein in the Presence of Therapeutic Monoclonal Antibodies. J. Proteome Res. 2018, 17, 1326-1333. [CrossRef]

11. Langerhorst, P.; Noori, S.; Zajec, M.; De Rijke, Y.B.; Gloerich, J.; van Gool, A.J.; Caillon, H.; Joosten, I.; Luider, T.M.; Corre, J.; et al. Multiple Myeloma Minimal Residual Disease Detection: Targeted Mass Spectrometry in Blood vs Next-Generation Sequencing in Bone Marrow. Clin. Chem. 2021, 67, 187. [CrossRef]

12. Milani, P.; Murray, D.L.; Barnidge, D.R.; Kohlhagen, M.C.; Mills, J.R.; Merlini, G.; Dasari, S.; Dispenzieri, A. The Utility of MASS-FIX to Detect and Monitor Monoclonal Proteins in the Clinic. Am. J. Hematol. 2017, 92, 772-779. [CrossRef] [PubMed]

13. Murray, D.; Kumar, S.K.; Kyle, R.A.; Dispenzieri, A.; Dasari, S.; Larson, D.R.; Vachon, C.; Cerhan, J.R.; Rajkumar, S.V. Detection and Prevalence of Monoclonal Gammopathy of Undetermined Significance: A Study Utilizing Mass Spectrometry-Based Monoclonal Immunoglobulin Rapid Accurate Mass Measurement. Blood Cancer J. 2019, 9, 1-7. [CrossRef]

14. Vachon, C. Comparison of MGUS Prevalence by Race and Family History Risk Groups Using a High Sensitivity Screening Method (MASS-FIX). Blood 2020, 136, 40-41. [CrossRef]

15. Mellors, P.W.; Dasari, S.; Kohlhagen, M.C.; Kourelis, T.; Go, R.S.; Muchtar, E.; Gertz, M.A.; Kumar, S.K.; Buadi, F.K.; Willrich, M.A.V.; et al. MASS-FIX for the Detection of Monoclonal Proteins and Light Chain N-Glycosylation in Routine Clinical Practice: A Cross-Sectional Study of 6315 Patients. Blood Cancer J. 2021, 11, 50. [CrossRef]

16. Abeykoon, J.P.; Murray, D.L.; Murray, I.; Jevremovic, D.; Otteson, G.E.; Dispenzieri, A.; Arendt, B.K.; Dasari, S.; Gertz, M.; Gonsalves, W.I.; et al. Implications of Detecting Serum Monoclonal Protein by MASS-Fix Following Stem Cell Transplantation in Multiple Myeloma. Br. J. Haematol. 2021, 193, 380-385. [CrossRef]

17. Eveillard, M.; Rustad, E.; Roshal, M.; Zhang, Y.; Ciardiello, A.; Korde, N.; Hultcrantz, M.; Lu, S.; Shah, U.; Hassoun, H.; et al. Comparison of MALDI-TOF Mass Spectrometry Analysis of Peripheral Blood and Bone Marrow-Based Flow Cytometry for Tracking Measurable Residual Disease in Patients with Multiple Myeloma. Br. J. Haematol. 2020, 189, 904-907. [CrossRef] [PubMed]

18. Mills, J.R.; Barnidge, D.R.; Dispenzieri, A.; Murray, D.L. High Sensitivity Blood-Based M-Protein Detection in SCR Patients with Multiple Myeloma. Blood Cancer J. 2017, 7, 590. [CrossRef]

19. Derman, B.A.; Stefka, A.T.; Jiang, K.; McIver, A.; Kubicki, T.; Jasielec, J.K.; Jakubowiak, A.J. Measurable Residual Disease Assessed by Mass Spectrometry in Peripheral Blood in Multiple Myeloma in a Phase II Trial of Carfilzomib, Lenalidomide, Dexamethasone and Autologous Stem Cell Transplantation. Blood Cancer J. 2021, 11, 19. [CrossRef]

20. Foureau, D.; Bhutani, M.; Guo, F.; Rigby, K.; Leonidas, M.; Tjaden, E.; Fox, A.; Atrash, S.; Paul, B.; Voorhees, P.M.; et al Comparison of Mass Spectrometry and Flow Cytometry in Measuring Minimal Residual Disease in Multiple Myeloma. Cancer Med. 2021, 10, 6933-6936. [CrossRef] [PubMed]

21. Santockyte, R.; Jin, C.; Pratt, J.; Ammar, R.; Desai, K.; Bolisetty, M.; Das, P.; Popa-McKiver, M.; Puig, O. Sensitive Multiple Myeloma Disease Monitoring by Mass Spectrometry. Blood Cancer J. 2021, 11, 78. [CrossRef]

22. McDonald, Z.; Liyasova, M.; Taylor, P.; Xu, X.; Gorospe, K.; Yao, C.; Liu, Q.; Yang, L.; Ma, B.; Piza, J.; et al. Targeted Mass Spectrometry-Based Serum M-Protein Monitoring for Early Relapse Detection. Blood 2019, 134, 4347. [CrossRef]

23. Puig, N.; Mateos, M.-V.; Contreras, T.; Paiva, B.; Cedena, M.T.; Pérez, J.J.; Aires, I.; Agullo, C.; Martinez-Lopez, J.; Rodriguez Otero, P.; et al. Qip-Mass Spectrometry in High Risk Smoldering Multiple Myeloma Patients Included in the GEM-CESAR Trial: Comparison with Conventional and Minimal Residual Disease IMWG Response Assessment. Blood 2019, 134, 581. [CrossRef] 
24. Avet-Loiseau, H.; San-Miguel, J.; Casneuf, T.; Iida, S.; Lonial, S.; Usmani, S.Z.; Spencer, A.; Moreau, P.; Plesner, T.; Weisel, K.; et al. Evaluation of Sustained Minimal Residual Disease Negativity with Daratumumab-Combination Regimens in Relapsed and/or Refractory Multiple Myeloma: Analysis of POLLUX and CASTOR. JCO 2021, 39, 1139-1149. [CrossRef] [PubMed]

25. Murray, D.L.; Puig, N.; Kristinsson, S.; Usmani, S.Z.; Dispenzieri, A.; Bianchi, G.; Kumar, S.; Chng, W.J.; Hajek, R.; Paiva, B.; et al. Mass Spectrometry for the Evaluation of Monoclonal Proteins in Multiple Myeloma and Related Disorders: An International Myeloma Working Group Mass Spectrometry Committee Report. Blood Cancer J. 2021, 11, 24. [CrossRef] [PubMed]

26. Kohlhagen, M.; Dasari, S.; Willrich, M.; Hetrick, M.; Netzel, B.; Dispenzieri, A.; Murray, D.L. Automation and Validation of a MALDI-TOF MS (Mass-Fix) Replacement of Immunofixation Electrophoresis in the Clinical Lab. Clin. Chem. Lab. Med. 2020, 59, 155-163. [CrossRef]

27. Moore, L.M.; Cho, S.; Thoren, K.L. MALDI-TOF Mass Spectrometry Distinguishes Daratumumab from M-Proteins. Clin. Chim. Acta 2019, 492, 91-94. [CrossRef]

28. Kohlhagen, M.C.; Mills, J.R.; Willrich, M.A.V.; Dasari, S.; Dispenzieri, A.; Murray, D.L. Clearing Drug Interferences in Myeloma Treatment Using Mass Spectrometry. Clin. Biochem. 2021, 92, 61-66. [CrossRef]

29. Thoren, K.L.; Pianko, M.J.; Maakaroun, Y.; Landgren, C.O.; Ramanathan, L.V. Distinguishing Drug from Disease by Use of the Hydrashift 2/4 Daratumumab Assay. J. Appl. Lab. Med. 2018, 3, 857-863. [CrossRef]

30. Kirchhoff, D.C.; Murata, K.; Thoren, K.L. Use of a Daratumumab-Specific Immunofixation Assay to Assess Possible Immunotherapy Interference at a Major Cancer Center: Our Experience and Recommendations. J. Appl. Lab. Med. 2021, 6, 1476-1483. [CrossRef]

31. Kumar, S.; Murray, D.; Dasari, S.; Milani, P.; Barnidge, D.; Madden, B.; Kourelis, T.; Arendt, B.; Merlini, G.; Ramirez-Alvarado, M.; et al. Assay to Rapidly Screen for Immunoglobulin Light Chain Glycosylation: A Potential Path to Earlier AL Diagnosis for a Subset of Patients. Leukemia 2019, 33, 254-257. [CrossRef] [PubMed]

32. Kourelis, T.; Murray, D.L.; Dasari, S.; Kumar, S.; Barnidge, D.; Madden, B.; Arendt, B.; Milani, P.; Merlini, G.; Ramirez-Alvarado, M.; et al. MASS-FIX May Allow Identification of Patients at Risk for Light Chain Amyloidosis before the Onset of Symptoms. Am. J. Hematol. 2018, 93, 368-370. [CrossRef] [PubMed]

33. Juskewitch, J.E.; Murray, J.D.; Norgan, A.P.; Moldenhauer, S.K.; Tauscher, C.D.; Jacob, E.K.; Murray, D.L. In from the Cold: M-Protein Light Chain Glycosylation Is Positively Associated with Cold Agglutinin Titer Levels. Transfusion 2021, 61, $1302-1311$. [CrossRef] [PubMed] 